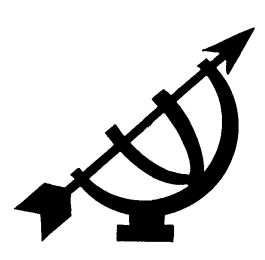

\title{
'n Analise van geselekteerde mediaberigte se uitbeelding van rassisme in Suid- Afrikaanse skole
}

Corene de Wet

Departement Vergelykende Opvoedkunde \& Onderwysbestuur Universiteit van die Vrystaat

BLOEMFONTEIN

E-pos: dewetnc@hum.uovs.ac.za

Abstract

An analysis of the portrayal of racism in South African schools in selected media reports

The influence of the printed media on the establishment of perceptions and as a source of information must not be underestimated. Although it is generally accepted that no editor will publish a report containing false information, there are many journalistic tricks of the trade that can be used in support of a specific political and/or economic view. In this article an attempt was made to find out how and with what purpose in mind the printed media, accused of perpetuating racism in the South African society, report on racial conflict and tension in education, a social relationship that also seems to be interlarded with racism.

\section{Inleiding}

Die (gedrukte) media het hulleself die rol van waghonde en toesighouers toegeëien en rapporteer gevolglik gebeure wat volgens húlle oordeel óf die algemene welstand van die breë gemeenskap bedreig óf vir die gemeenskap van belang is. 1 Verslaggewing behels egter méér as die kliniese weergee van gebeure - aktuele aangeleenthede word geïnterpreteer, geanaliseer en geëvalueer (Van Deventer, 1990:218; Black \& Whitney, 1989:9-16; Newton, 1989:4). Die media het 'n plig om die leserspubliek deur kennis te bemagtig sodat hulle ingeligte besluite kan

$1 \quad$ Vergelyk Strelitz \& Steenveld (1998:100-110); Wanta \& Mahmoud (1991:47-49); Black

\& Whitney (1989:9-16); Newton (1989:4); Mytton (1983:8); MacDougall (1977:24); Snyman $(1971: 49,65)$. 
neem en verantwoordelik kan optree (Froneman, 1997:5; Van Deventer, 1990:218; Muller, 1990:227). Muller (1990:227) is van mening dat dit die taak van die koerant is "om die verwarrende tydperk waarin ons leef te probeer ontleed en sin daarvan te probeer maak. Koerante kommentarieer nie net die politiek nie, maar in werklikheid word ook van hulle verwag om 'n nuwe wêreld te help skep". Indien hierdie singewing egter 'n skeefgetrekte werklikheid is, sal dit nie in ooreenstemming wees met hulle Godgegewe kulturele mandaat nie (kyk Froneman, 1997:5-14 vir 'n Christelike media-model). Snyman (1971: 40:240) wys daarop dat binne die raamwerk van 'n koerant wat Christelike norme eerbiedig, die joernaliste se geloofsoortuiging rigting aan hulle roepingsvervulling behoort te gee. Onder roepingsvervulling word onder andere die volgende verstaan: natuurbeheersing, kultuurvorming, sorg aan die mens en diens aan God. Die situasie kan egter ontstaan dat joernaliste hul opdrag wil uitvoer, maar dat die leserspubliek dit onmoontlik kan maak as gevolg van leseren nuustamheid (Muller, 1990:229-300). Die gevaar bestaan dat leserbehoeftes die inhoud van koerante dikteer, want 'n koerant sonder lesers is gedoem.

Hoewel die meerderheid mediaberigte vanuit 'n spesifieke politieke en/of ekonomiese verwysingsraamwerk en/of geloofsoortuiging geskryf word (kyk Hartley, 1985:8; Merrill, 1984:82; Snyman, 1971:242), word dit volgens MacLean (1988:167) en MacDougall (1977:20-21) algemeen aanvaar dat geen redakteur met opset 'n berig wat valse inligting bevat, die wêreld sal instuur nie. Dat die Suid-Afrikaanse bevolking dié siening onderskryf, blyk uit navorsing wat in November 1999 deur die Raad vir Geesteswetenskaplike Navorsing onderneem is. Volgens dié navorsing vertrou 66 \% van die Suid-Afrikaanse bevolking die media (Steek, 2000:4). Die werklikheid (nuus) wat die joernalis aan sy/haar lesers voorhou, is nie 'n objektiewe werklikheid nie, dit is 'n geïnterpreteerde werklikheid. Hoewel daar kriteria in die literatuur bestaan oor wat nuuswaardig is (onder andere tydigheid, bereikbaarheid van die toneel, konflik, belangrike persone, konfliksituasie en menslikheidsaspek - vgl. Froneman, 1997:10), is daar verskillende sienings oor wat nuus is (Froneman, 1997:11; McQuil, 1987:204-205; MacDougall, 1977:11). Vir Froneman (1997:11) hoort nuus nie net 'n refleksie van gebeure in 'n gemeenskap te wees nie, maar moet dit ook dié gemeenskap se probleme en belangstellings reflekteer. En een van dié probleme is rassisme in die onderwys. Uit 'n Suid-Afrikaanse Menseregtekommissieverslag blyk dit dat die tweede hoogste persentasie klagtes wat deur die regsafdeling van dié kommissie ontvang is, rondom onderwysaangeleenthede gewentel het (SAHRC, 1999b:10; Bonthuys, 1999:2).

Uit voorleggings aan die Suid-Afrikaanse Menseregtekommissie (SAHRC, 1999a:13-18), asook verbandhoudende navorsing (kyk o.a. 
Newton, 1989:4; Van Dijk, 1987:124, 153; Oosthuizen, 1982:47) blyk dit dat die invloed van die media in die vestiging van persepsies en as inligtingsbron nie onderskat moet word nie. Van Deventer (1990:218) verwys byvoorbeeld na die rol wat die Afrikaanse pers in "die veredeling van Afrikanerdenke" gespeel het. Die media word as een van die belangrikste inligtingsbronne oor rasseaangeleenhede in die algemeen en rassisme in die besonder beskou (Van Dijk, 1987:124; Jones, 1997: 176; Troyna \& Hatcher, 1992:135-141). Rassisme, wat gedefinieer kan word as die regverdiging van rassemeerderwaardigheid en die oorheersing van een rasgroep deur ' $n$ ander op grond van biogenetiese en kultuurverskille (Benedict, 1943:97; Teffo, 1994:65; Brook, 1996:204; Rigby, 1996:28; SAHRC, 1999a:17), word ten strengste deur die SuidAfrikaanse regering verbied (RSA, 2000, Wet no. 4, artikel 7; Gunning, 2000:4). Wetgewing is egter nie genoeg om rassisme uit die SuidAfrikaanse samelewing te weer nie. Blank én swart moet rassisme as 'n realiteit in die Suid-Afrikaanse samelewing erken en beveg, aldus Thabo Mbeki (2000a:7; 2000b:2). Hy (Mbeki, 2000b:2) bepleit 'n "humane and people-centred society". Om dié doelstelling in die Suid-Afrikaanse samelewing in die algemeen, en die onderwys in die besonder (James, $2000: 4-5)$ te bereik, is 'n ingeligte samelewing, wat ook eties-verantwoordelike besluite neem, nodig.

Die media, wat rassisme in die Suid-Afrikaanse samelewing skynbaar laat voortbestaan, $\mathbf{2}$ moet die leserspubliek en onderwysbelanghebbendes sensitief instel op rassisme in 'n samelewingsverband waarin rassisme skynbaar hoogty vier (Bhana, 1999:20). Teen die agtergrond van dié probleem is die doel van hierdie artikel om deur middel van 'n kwalitatiewe en kwantitatiewe inhoudanalise die volgende probleemvrae te probeer beantwoord:

- Hoe word rassekonflik en -spanningsituasies in die onderwys deur die gedrukte media uitgebeeld?

- Wat is die onderliggende doelstellings van die gedrukte media met die rapportering van rassekonflik- en spanning by skole?

- Kom die perswese hul selfopgelegde taak as waghonde en toesighouers na deur dade van rassisme aan die kaak te stel, of adem die Suid-Afrikaanse perswese 'n gees van sensasionalisme?

2 Kyk Mathiane (2000:03-07:1); SAHRC (1999a:3); SAHRC (2000a:1-3); SAHRC (2000b:1-2); Die Volksblad (1995-06-01:2). 


\section{Navorsingsmetodologie}

In 'n rekenaarsoektog wat op 15 Maart 2000 by die Instituut vir Eietydse Geskiedenis (Universiteit van die Vrystaat) geloods is, het 'n kombinasie van die sleutelwoorde rassisme en onderwys 2539 raakpunte gelewer vir koerantberigte wat gedurende die periode 1985 tot Februarie 2000 in Suid-Afrika gepubliseer is. Daar word dus omvattend in die gedrukte media oor rassisme in die onderwys gerapporteer. Weens die groot getal mediaberigte oor rassisme in die onderwys is slegs 'n seleksie van dié berigte bestudeer. Berger (1991:28) wys daarop dat dit altyd problematies is om te bepaal hoe verteenwoordigend die steekproef (berigte) is. Om die probleem te omseil poog inhoudanaliste om 'n redelike groot getal berigte te analiseer. Vir die doel van hierdie artikel is gefokus op koerantberigte wat sedert 1985 verskyn het. 3 Voorkeur is aan berigte met 'n vergelykingspotensiaal gegee. 4 Geen aandag is aan redaksionele kommentaar geskenk nie, omdat dié kommentaar juis 'n koerant se onderliggende beleid weergee (Fowler, 1991:208, 221). Daarenteen behoort nuusberigte betroubare, onverdraaide, akkurate en onbevooroordeelde nuus te bevat. 5

Ter bereiking van gestelde doelwitte is van kwalitatiewe en kwantitatiewe inhoudanalise gebruik gemaak. Deur kwalitatiewe inhoudanalise word gewoonlik gepoog om deur kritiese analise antwoorde op vooropgestelde probleemvrae te verkry. Kwantitatiewe inhoudanaliste let op die frekwensie van geselekteerde simbole, woorde en beelde in die media. 6 Inhoudanalise werp lig op 'n spesifieke koerant se persepsie van die werklikheid. 'n Koerant se werklikheid verskil dikwels aansienlik van die kwantifiseerbare werklikheid. Tweedens kan deur inhoudanalise vasgestel word of 'n spesifieke koerant 'n sekere politieke party, kultuurgroep of ras belangriker as 'n ander ag. Deur die taal, simbole, prente en argumente te ontleed, is dit moontlik om 'n kykie in 'n spesifieke koerant se siening van sy leserspubliek te verkry. Voorts is dit soms moontlik om deur

3 Sedert 1985 is swart leerders in tradisionele blanke staatskole toegelaat.

$4 \quad$ Naas waarneming, kontekstualisering en sensitisering is vergelyking 'n belangrike kriterium vir kwalitatiewe navorsing (kyk Christians \& Carey, 1981:347-362).

$5 \quad$ Kyk Froneman (1997:6-7) vir 'n Christelike gedragskode vir joernaliste en Merrill et al. (1990:403-405) vir die gedragskodes van die Internasionale Organisasie vir joernaliste.

6 Vir besprekings van kwalitatiewe en kwantitatiewe inhoudanalise-metodologie kyk onder andere Berger (1991:31-35); Jankowski (1991:163-174); Thomas (1990:15); Hsia (1988:283-290); McQuil (1987:176-179); Christians \& Carey (1981:342-362); Stempel (1981:119-131). 
inhoudanalise die invloed van 'n spesifieke berig op die waarskynlike leser te bepaal (Windahl et al., 1998:133-134; Berger, 1991:27-30; DeFleur \& Dennis, 1985:383-386).

\section{3. "Die waarheid en niks anders as die waarheid nie"}

In hulle voorlegging aan die Suid-Afrikaanse Menseregtekommissie oor rassisme in die media plaas Media Review Network 'n vraagteken agter die geloofwaardigheid van mediaberigte: "the media ... should be noted as being sensational, unverified and inaccurate" (SAHRC, 1999a:18). Dié beskuldiging is in stryd met die algemeen aanvaarde joernalistieke beginsel dat geen koerant bewustelik valse inligting sal publiseer nie (kyk o.a. McQuil, 1993:184; Merrill et al., 1990:403-405; MacDougall, 1977: 24). Nie alle joernaliste en/of redakteurs voel hulle gebonde aan dié beginsel nie. Sommige van hulle maak gebruik van vakgeheime wat hulle in staat stel om die waarheid subtiel of blatant te verdraai (MacLean, 1988:37-39). Selektiewe verslaggewing en die aanbied van "halwe waarhede" kom redelik algemeen voor. Persone word dikwels onvolledig en/of buite konteks aangehaal. Baie berigte is slegs gebou op die getuienis van diegene wat 'n spesifieke standpunt ondersteun. Berigte is soms deurspek met ongegronde spekulasies, sinspelings, asook vae veralgemenings. McQuail (1993:194) wys daarop dat dit moeilik is om onbewuste, verskuilde vooroordele en persepsies in 'n mediateks met behulp van 'n inhoudanalise te identifiseer, aangesien hierdie verskuilde vooroordele en persepsies dikwels bestaan met die weglating van gegewens of die subtiele taal- en/of berigstrukturering. Onbewuste, maar openlike vooroordeel en persepsies is makliker identifiseerbaar en sluit onder andere die keuse van onderwerp en die gebruikmaking van sekere inligtingsbronne in.

Om die waan van objektiwiteit te handhaaf, weerhou sommige joernaliste hulle daarvan om in hulle beriggewing van rassekonflik by skole kommentaar te lewer. Dié berigte is in wese 'n samevoeging van onderhoude met betrokkenes en/of belanghebbendes. Dit is egter belangik om te let op wie die joernaliste aanhaal (Van Dijk, 1993a:252-254). Die keuse van bronne lei tot nuanseverskille tussen berigte. Sommige van die berigte wat bestudeer is, is oorwegend positief en wys byvoorbeeld op stappe wat geneem is om konflik uit te skakel en positiewe houdingsveranderinge by lede van die skoolgemeenskap. Slegs die getuienis van diegene wat positief teenoor 'n geïntegreerde skolestelsel staan, word in dié berigte aangehaal.7 In twee berigte in The Cape Times (1996-09- 
06a:4; 1996-09-06b:4) word byvoorbeeld deur middel van aanhalings uit onderhoude met leerders en opvoeders 'n feitlik idilliese skoolmilieu en -gemeenskap geskilder. Hierdie aanhalings teken 'n situasie waarin swart en blanke leerders, opvoeders en lede van die breë gemeenskap in rasseharmonie werk en speel.

Daarenteen is sommige berigte feitlik ' $n$ inventaris van rassistiese optrede en haatspraak deur óf blanke ${ }^{8}$ óf swart ${ }^{9}$ leerders, opvoeders en ouers. Simpatie word in dié berigte gewek vir óf die blanke óf die swart leerders en opvoeders, wat feitlik weerloos staan teenoor die blatante rassisme van hulle mede-leerders en opvoeders.

\section{Selektiewe verslaggewing en bronbenutting}

In hierdie onderafdeling van die artikel word gefokus op enkele gevalle van selektiewe verslaggewing. Die selektiewe beriggewing en bronbenutting, halwe waarhede en sinspelings word duidelik geïllustreer in twee uiteenlopende berigte in Beeld en City Press oor rassekonflik by 'n nywerheidskool buite Ogies in Mpumalanga (Coetzee, 1997:3; Mlambo, 1997:10). In 1997 het dié skool onderrig verskaf aan 187 leerders, waarvan dertien blank was. Na klagtes deur sommige van die blanke leerders dat van hulle eiendom deur swart kamermaats gesteel is, en sommige van hulle gesodomiseer en aangerand is, het die skoolhoof besluit om die blanke leerders in aparte slaapkamers te plaas. Die uitvoering van dié besluit het tot rassekonflik gelei (Coetzee, 1997:3; Mlambo, 1997:10). In die twee berigte is daar nie net direkte teenstrydighede nie, maar ook klemverskille en onderskeid oor wie die aggressor en wie die lydende party is. Uit Coetzee (1997:3) se berig blyk dit dat leerders deur howe na dié skool verwys is nadat hulle skuldig bevind is aan ernstige misdade soos moord, roof, verkragting en motorkapings. Uit Mlambo (1997:10) se berig lyk dit asof die oortredings wat deur die leerders gepleeg is van 'n minder ernstige aard was as wat Coetzee beweer (Mlambo belig byvoorbeeld diefstal uit motors, sakkerollery en bandeloosheid). Voorts skryf Mlambo (1997:10) dat die meerderheid van dié leerders op versoek van hulle ouers, en ter wille van

Lange (1997:3); Rapport (1997-05-18:12); The Cape Times (1996-09-06a:4); The Cape Times (1996-09-06b:4); Pillay (1995:5).

8 Dlamini (1999:2); Mangxamba (1999:10); Ledwaba (1999b:4); Mamalla (1999:4); Ledwaba \& Makgotha (1999:1); Mulaudzi (1999:4); Lebwaba \& Sakuneka (1999:1); Naidoo (1999:3); Bissetty (1998:3); Eastern Province Herald (1995-09-19:4); Siluma (1995:28). 
rehabilitasie, in dié skool geplaas is. Coetzee (1997:3) gee 'n uitvoeringe beskrywing van vandalistiese dade wat deur sommige van die swart leerders by die skool gepleeg is. Simpatie word met die blanke leerders gewek wat moes ly as gevolg van swart leerders se geweldsoptrede. Ook word byvoorbeeld gerapporteer dat sommige van die blanke opvoeders verplig was om die blanke leerders in die siekeboeg toe te sluit om hulle teen verdere aanvalle te beskerm en dat die swart personeel en koshuisbeamptes, wat veronderstel was om die kinders te beheer, die swart leerders opgesweep het. Volgens Coetzee (1997:3) het hulle "slagspreuke van apartheid en rassisme ... geskreeu, terwyl vergaderings gehou is". Volgens dié berig is die hulp van die polisie ingeroep omdat daar vir die lewe van die leerders en opvoeders gevrees is en was die polisie verplig om 'n traangranaat en ses rubberkoeëls af te vuur omdat hulle met klippe bestook is. Coetzee meld ook dat polisie- en personeelvoertuie beskadig is.

Bogenoemde gegewens strook egter nie met Mlambo (1997:10) se weergawe nie. Volgens hom het "hordes of policemen", gewapen met traangas en rubberkoeëls, die skool bestorm nadat swart leerders teen rassisme betoog het. In dié berig is geen verwysings na vandalistiese dade of geweldsoptrede deur dié leerders nie. Inteendeel, daar word simpatie met hulle gewek. Volgens Mlambo (1997:10) het sommige van die swart leerders die beskuldiging gemaak dat hulle nie net met die dood gedreig is nie, maar ook mishandel is. Voorts word die persepsie geskep dat dié optrede en dreigemente die rede is waarom sommige van die swart leerders uit die skool ontsnap het. Simpatie word deur die aard van die beriggewing met die ontsnaptes gewek, want daar word gemeld dat hulle geen geld by hulle gehad het nie en dat hulle hulle tot misdaad sou moes wend om aan die lewe te bly. In albei dié ondersoekende berigte word gesuggereer wie die aggressors is en gevolglik die blaam vir die konflik moet dra. Vanuit hulle onderskeie verwysingsraamwerke het die twee joernaliste die "skuldiges" in die media verhoor en skuldig bevind. In hierdie opsig word die reg van die media om dade van rassisme bloot te lê, nie ontken nie. Daar moet egter gepoog word om minder subjektief te rapporteer.

In sommige berigte is werklik gepoog om die standpunte van albei die botsende rassegroepe in gebalanseerde beriggewing te akkommodeer. In dié berigte word, sonder om kommentaar te lewer, gerapporteer oor 
die ervaringe en sieninge van sowel blanke as swart leerders, ouers en opvoeders. 10

- Hoewel Thompson (1998a) ook poog om die skyn van objektiwiteit in sy beriggewing oor rassekonflik by Hoërskool Schweizer-Reneke te wek, is 'n klemverskuiwing in opeenvolgende berigte te bespeur. In 'n berig in Beeld van 6 Februarie 1998 slaag Thompson (1998a:1) daarin om die ervarings en standpunte van blanke en kleurlingleerders, ouers en ander rolspelers ten tyde van die konflik redelik gebalanseerd weer te gee. In 'n daaropvolgende berig (Thompson, 1998b:1) word op simpatieke wyse gekonsentreer op die kleurlingleerders en -gemeenskap se belewing van die rassekonflik by die skool. Hulle word as die lydende party geskets. Volgens dié berig het sommige van die blanke opvoeders hulle skuldig gemaak aan haatspraak, die geweldsoptrede van die blanke seuns teen die kleurlingleerders goedgekeur en geweier om hulp te verskaf aan een van die kleurlingleerders, wat "bedwelmd hulp gaan soek het".

- Sommige koerantberigte laat geen twyfel oor die onderskeie verwysingsraamwerke van die joernaliste nie. Ter inleiding van sy berig oor toestande by die Vryburg Hoërskool skryf Ledwaba (1999:4): "There are two worlds at Vryburg High School". Hy skets dié twee wêrelde as onversoenbare werklikhede. Die bevoorregte blanke leerders en opvoeders laat die apartheidsonderwysstelsel voortbestaan deur onder andere te weier om Nkosi Sikelel' iAfrika te sing, die ou nasionale vlag in klaskamers ten toon te stel en wit en swart leerders apart in klaskamers te laat staan. Daarenteen spreek die berig van simpatie met swart leerders en opvoeders. Volgens Ledwaba misgun die bevoorregtes die swart leerders, wat elke dag ses kilometers moet stap om by die skool te kom, toegang tot die onderrig van rekenaarstudie, tegniese vakke en tik. Ook berig Ledwaba dat die swart leerder nie aan skyfskiet mag deelneem nie en geïgnoreer word wanneer sportspanne saamgestel word, hoewel hulle ouers dieselfde skoolfondse as blanke ouers betaal. Vir die swartes by dié skool is dit volgens Ledwaba (1999:4) "an uphill struggle".

- In 'n koerantberig met die subopskrif "Nothing but the truth", laat Mogale (1999:6) geen twyfel by die leser oor wat volgens hom die waarheid is nie. 'n Twaalfjarige swart leerder van Ficksburg wat van seksuele teistering aangekla is, was volgens Mogale (1999:6) "blissful

10 Kyk o.a. Versluis (1998:2); De Kock (1998:12); Joubert (1998:4); Anstey \& Ledwaba (1997:5); De Kock (1997:12); The Citizen (1997-05-16:3); Sunday Times (1997-0518:5). 
in his confusion and ignorance" oor wat veronderstel was dat hy verkeerd gedoen het en het die lede van die blanke beheerliggaam voor die dissiplinêre verhoor met die beweerde slagoffers gekoukus. Reeds voor die verhoor was die bevindinge volgens die joernalis ' $n$ uitgemaakte saak. Mogale (1999:6) reken dat "Ficksburg Primary School ought to hang its head in shame".

- In 'n baie eensydige berig rapporteer Raboroko (1997:5) oor 'n aanval op 'n elfjarige swart seun deur twee blanke medeleerders. Volgens dié berig het Lucian Nku bloot op die stoep van die skoolgebou geloop toe hy sonder rede wreed deur twee blanke medeleerders aangeval is. Volgens die seun se moeder het die kliniekgeneesheer gedreig om haar seun nie te behandel nie as sy 'n klag teen die seun se aanvallers by die polisie sou lê. Simpatie word met die moeder gewek sy moes kies tussen reg en geregtigheid en die lewe van haar seun. Sy omseil die dilemma deur vir die geneesheer te lieg, "because I feared my child would bleed to death". Die berig is uitsluitlik op 'n onderhoud met die moeder gebaseer. Hoewel daar genoem is dat sy die saak by die polisie, skoolhoof en kliniekgeneesheer aangemeld het, is skynbaar geen moeite gedoen om die getuienis van genoemde volwassenes of van die twee blanke medeleerders in te win of te rapporteer nie. Die enigste sprake van verifiëring is die feit dat 'n woordvoerder van die polisie bevestig het dat hulle die insident ondersoek.

Nie die swartes nie, maar die blankes is volgens Die Afrikaner (1999-07$02: 12)$ die verloorders in die blank-swart-skolekonflik. Volgens dié koerant moet die aanstelling van 'n swart adjunkhoof by die Vryburg Hoërskool, wat nie deur die beheerliggaam van die skool nie, maar teenstrydig met normale prosedures, eensydig deur die Noordwesonderwysdepartement afgedwing is, as 'n "oorwinning" oor die blanke beheerliggaam gesien word. Dié aanstelling is 'n "uittarting van die blanke gemeenskap [en] ... verseël finaal die nederlaag van die blanke gemeenskap van Vryburg in die rasse-onluste", aldus Die Afrikaner (1999-07-02:12). In teenstelling met dié berig, waarin die aanstelling van 'n swart adjunkskoolhoof betreur word, bring Sylvester (1999:6) lof aan die adjunkskoolhoof, mnr. M.B. Fuleni. Uit dié berig blyk dit dat Fuleni beplan om deur woord en daad rasseharmonie in die skool te vestig.

Sommige van die joernaliste is skynbaar van mening dat hulle nie net die leserspubliek moet inlig nie, maar dat hulle ook in gesprek moet tree met kollegas wat nie dieselfde politieke siening as hulle deel nie. $\mathrm{Na}$ aanleiding van beriggewing oor rassebotsing by 'n Kaapse skool, skryf Van de Graaf (1995:2): "Die media het ... sogenaamde 'rassistiese' opmerkings van enkele ouers uitgebuit in 'n poging om die swartes in die 
gelyk te stel en die blankes tot misdadigers verklaar te kry". Terwyl Van de Graaf kritiek lewer teen wat hy as 'n anti-blanke pers beskou, trek Jassat en Ahmed (1999:18) te velde teen die Eurosentriese benadering van die Suid-Afrikaanse perswese: "The idiosyncracies of a media rooted in Eurocentrism has never been more pronounced in bringing to the fore paradoxes, inconcistincies and downright follies than in the 'Layla Cassims Affair'".11

Dat insidente van rassisme by skole plaasvind, is 'n gegewe. Dit lyk egter asof daar soveel "waarhede" bestaan oor wat presies by skole gebeur, as wat daar joernaliste en/of koerante is. Hoewel feitlik alle koerantberigte aan redaksionele goedkeuring onderworpe is, is die feit dat die meerderheid van die geraadpleegde koerantberigte erkenning aan die betrokke joernaliste gee, 'n bewys van die joernalistieke eienaarskap van die betrokke berigte. Dié joernaliste aanvaar dus intellektuele en morele verantwoordelikheid vir die "waarhede" in hulle berigte. Dit beteken nie dat anonieme beriggewing carte blanche aan die skrywers van dié berigte verleen nie. Koerantberigte word skynbaar kritiekloos deur 'n groot persentasie van die Suid-Afrikaanse leserspubliek as waar aanvaar. Die blaam vir hierdie byna naïewe aanvaarding van 'n dikwels skeefgetrekte werklikheid moet nie net geplaas word op die skouers van joernaliste en redakteurs, wat hulle vertrouensposisie misbruik nie - 'n kritiese en bevraagtekenende leserspubliek is noodsaaklik. Snyman (1971:194) wys tereg daarop dat hoewel daar geen gesagsverhouding tussen die joernalis en die leserspubliek bestaan nie, daar 'n toerekeningsbaarheidverhouding tussen hulle bestaan. Van die joernalis kan rekenskap verwag word vir wat hy/sy meedeel en van die leser 'n kritiese ingesteldheid.

\section{Blaamverplasing}

Rassisme is onlosmaaklik deel van die Suid-Afrikaanse geskiedenis en samelewing. Onderwys is ' $n$ kernaangeleentheid in dié samelewing. Om die onderwys en rassisme ter ondersteuning van politieke argumente te gebruik, is gevolglik redelik algemeen in koerantberigte. Rassekonflik by skole moet volgens Die Afrikaner (1998-02-13:5) en Van de Graaf (1995) direk aan die regering se integrasiebeleid toegeskryf word. Terwyl in die aangehaalde berigte fel kritiek teen integrasie uitgespreek word, loods Southern Africa Report 'n aanval teen apartheid. Die blaam vir rassekonflik by skole word deur die Southern Africa Report (1995-04-21:5;

11 Layla Cassims, 'n Moslem-leerder, is gevra om haar skool te verlaat omdat sy na bewering in 'n opstel oor Palestina 'n anti-Semitiese standpunt gehuldig het (Jassat \& Ahamed, 1999:18). 
1996-02-02:4) voor die deur van apartheid gelê. Die Southern Africa Report (1995-04-21:5) regverdig die gewelddadige optrede van swart leerders teenoor hulle mede-(kleurling-)leerders, want laasgenoemde het hulle steun in die Wes-Kaap aan die "oppressors", die Nasionale Party, toegesê. Dié publikasie toon begrip vir die geweldsoptrede van die swartes, want hulle was met bitterheid gevul. Die Southern Africa Report (1996-02-02:5) toon egter ook begrip vir die blankes se ontevredenheid oor die skoolintegrasie in Potgietersrus: "The Potgietersrus incident is to be expected in this higly conservative region of the Transvaal where many rightwingers have also not yet come to terms with changes in the new SA". Wat werklik by dié skole gebeur het, is dus nie vir dié publikasie relevant nie. Oorsake vir rassekonflik word buite die skoolsituasie gesoek en dié konflik word skietgoed vir aanvalle teen apartheid.

Reeds voor die totstandkoming van die demokratiese bestel in SuidAfrika is die mening deur sommige joernaliste geopper dat apartheidsonderwys as die onderliggende oorsaak van rassisme in die land beskou moet word (Evening Post, 1985-02-05:6; Marinovich, 1992-10-07:6). 'n Opskrif in the Evening Post (1985-02-05:6) lui: "Apartheid education at root of race prejudice". Apartheid oor die algemeen, en die Afrikaner in die besonder, word deur Sunday Word (1999-03-07:4) vir rassekonflik by skole geblameer.

Daarenteen plaas Die Afrikaner (1999-04-30:1) alle blaam vir rassekonflik op die skouers van die swartes - hulle tree uittartend teenoor blanke leerders op, betas sommige van die dogters en besig vulgêre taal. 'n Blanke seun wat een van die swart seuns "'n ordentlike loesing" gegee het, het bloot "instinktief" opgetree. Presies die teenoorgestelde prentjie word deur Monare (1999:1) geskets. Die rolspelers se rasse verander bloot. In die plek van die weerlose dogters wat deur swartes geteister is, is daar nou 'n graad 3-kleurlingseun wat pas 'n oogoperasie ondergaan het en deur 'n blanke ouer aangeval is. Op simpatieke wyse verhaal Monare hoe die kleurlingseun, wat nie met 'n blanke leerder wou speel nie, op sinlose wyse eers deur dié leerder geskop en daarna deur die seun se pa met die kop gestamp is.

Die voorafgaande bespreking bevestig Snyman (1971:242) se siening dat geen joernalis neutraal is nie. Elke joernalis het 'n eie perspektief, 'n eie oriëntering, en hy/sy moet hom/haar daaroor verwoord. Hierdie gebrek aan neutraliteit het daartoe gelei dat joernaliste teenstrydige sondebokke vir die rassekonflik by skole geïdentifiseer het: die apartheidstelsel, maar ook die geïntegreerde skolestelsel; die blankes maar ook die swartes. Die uiteenlopende blaamlegging het tot gevolg dat daar in verskeie berigte 'n vir en 'n teen, 'n aggressor en 'n lydende party is. 
En dié joernaliste poog nie om die belewing van alle betrokkenes weer te gee nie. Beriggewing oor rasse-insidente ontbloot nie net die onverdraagsaamheid van joernaliste teenoor diegene wat nie hulle sienings onderskryf nie, maar bied ook aan hulle die geleentheid om blankes en/of swartes positief en/of negatief te stereotipeer.

\section{Stereotipering}

Die media speel 'n belangrike rol in die vestiging en instandhou van stereotiperings, want "stereotypes are not based on thin air; there is usually a kernel of truth" (Jones, 1997:168). Uit voorleggings aan die Suid-Afrikaanse Menseregtekommissie blyk dit dat rasstereotipering algemeen in die Suid-Afrikaanse gedrukte media voorkom (SAHRC, 1999a:13-18).

Een van die negatiefste berigte wat vir die doel van hierdie artikel onder oë geneem is, is dié van Van de Graaf (1995:2). Nadat die Ruyterwachtskool in die Kaap "oorstroom" is met swart leerders, wat hulle "totaal misdra" het, is die skool, "wat in 'n perfekte toestand was [binne 'n paar dae] tot 'n gesondheidsrisikogebied verklaar". Uit dié berig blyk dit dat die swart leerders bad- en klaskamers verniel het, hulle "oorgegee het aan hulle welluste" deur openlik dagga te gebruik, en dat sommige van hulle "oop en bloot op die gras van die skool seksueel met mekaar verkeer" het. Blanke leerders is ook geïntimideer en aangerand. Hoewel dit nie die doel van hierdie artikel is om die waarheid van die beskuldigings te bevraagteken nie, moet gemeld word dat Van de Graaf geen verifiëring vir sy beskuldigings verskaf nie. In die berig word swart leerders as seksbehepte, daggarokende, vernielsugtige geweldenaars en intimideerders gestereotipeer. Dié negatiewe stereotipering dien by implikasie as regverdiging vir Van de Graaf (1995:2) se pleidooi vir gesegregeerde onderwys. Berry en Tischler (1978:247) waarsku dat negatiewe rasstereotipering tot die regverdiging van rassisme kan lei, want "the fault lies with the minority group itself, for it is ... addicted to immoral, filthy, dishonest, and treacherous habits". Die mens, die beelddraer van God, word deur stereotipering tot 'n karikatuur gereduseer.

Terwyl Van de Graaf die swart leerders negatief stereotipeer, word mindergegoede Afrikaanssprekende ouers soms as bekrompe en kru gestereotipeer. Na Ficksburg word byvoorbeeld verwys as 'n "conservative dorpie" (Mogale, 1999:6). Groot gewag word gemaak van die feit dat die Elandspoort Hoërskool, waar ouers hulle hewig teen skoolintegrasie verset het, in 'n oorwegend middelklas Afrikaanssprekende woonbuurt geleë is (Eveleth, 1997:6; Anstey \& Ledwaba, 1997:5). In 'n Engelstalige koerant (kyk Anstey \& Ledwaba, 1997:5) word 'n negatiewe beeld van die ouers geskets - sommige van hulle was skynbaar besope 
en het die Sunday Times-verslaggewer met geweld gedreig. 'n Blanke moeder het glo op 'n swart leerder gespu.

In Die Afrikaner (1999-04-30:1) word 'n blanke seun, wat 'n swart leerder te lyf gegaan het, as 'n onverskrokke held voorgestel. Hy het "instinktief" opgetree, die swart leerder "stormgeloop, en hom deeglik afgeransel [en] ... 'n ordentlike loesing gegee". Van de Graaf (1995:2) is vol lof vir blanke ouers wat "gewapen met sambokke, swepe en tuingereedskap ... besluit het om hulle kinders te beskerm". Dit wat deur die Engelstalige koerante negatief gestereotipeer word, word in die voorafgaande twee berigte positief uitgebeeld. Die Afrikaners wat in opstand kom teen 'n geïntegreerde skolestelsel word as die "redders" van die Afrikanervolk gestereotipeer. Daarteenoor word diegene wat nie bereid is om tot die konflik toe te tree nie, uitgebeeld as kapituleerders (Die Afrikaner, 199909-10:12).

Rasstereotipering word deur die media in stand gehou en uitgebou. Dit plaas 'n ernstige struikelblok op die weg van rasseharmonie by skole. As gevolg van stereotipering word sekere valse of verdraaide bevolkingskarakteristiek as gegewe aanvaar. Deur negatiewe stereotipering word die mens, op grond van ras tot tipe gereduseer. Die vertrouensposisie wat die media by die leserspubliek geniet, moet nie misbruik word om negatiewe stereotiperings te vestig nie, maar om dit af te breek. En dit kan slegs geskied deur eerlike en gebalanseerde beriggewing. Vanuit sy/haar gees beïnvloed die joernalis die lesers, spreek hy/sy hulle gesindhede aan, steek hy/sy hulle aan met sy/haar positiewe gees.

\section{Emosionele terme}

In die gedrukte media is die woord die belangrikste nuusdraer. Die geïmpliseerde betekenis en emosionele konnotasie van woorde moet nie onderskat word nie (Van Dijk, 1993a:263; 1993b:106). Die gebruik van terme soos "Afrikanerdom" (Ledwaba, 1999a:4), "apartheid school" (Ledwaba \& Sakuneka, 1999:1), "vintage South Africa" (Mogale, 1999:6) en "oppressors" (verwysend na die eertydse Wes-Kaapse regering) (Southern Africa Report, 1995-04-21:5) laat geen twyfel by die leser dat dié berigte vanuit ' $n$ anti-apartheidsverwysingsraamwerk geskryf is nie. Daarenteen dui die gebruik van 'n term soos "ANC-regime" (Die Afrikaner, 1999-12-03:2), asook die koerantopskrif "ANC speel woerwoer met Kuschke" (Die Afrikaner, 1999-09-10:12) op kritiek teen en minagting vir die ANC-regering.

Dit wil voorkom asof sommige joernaliste in hulle beskrywing van konfliksituasies beelde van uiterste geweld wil oproep. Daar word onder andere verwys na "school at war" (Anstey \& Ledwaba, 1997:5), "gevegte" 
(De Kock, 1997:12), 'n "woeste geveg" (Thompson, 1998:1) en 'n "oorloggie" (De Kock, 1998-:12). Volgens De Kock (1997:12) het blanke en swart ouers by Elandspoort "mekaar met maanhare orent staan en dophou ... [en] 'n mens kon feitlik al die lont van die kruitvat begin ruik". Volgens De Kock (1998:12) het Vryburg "sy wonde gelek na 'n week van rasse-onluste waarin skoolkinders met sambokke geslaan, petrolbomme gegooi en geboue en motors aan die brand gesteek is. Dit het in 'n stadium na 'n oorlog in die kleine gelyk".

Sirkulasiesyfers en sensasionele beriggewing mag nooit ten koste van eerlike beriggewing nagejaag word nie. Die gevaar bestaan dat die gebruik van dramatiese en emosionele beskrywings rassekonflik by skole kan aanwakker. Die media moet nooit as gevolg van opruiende beriggewing die oorsaak van rassekonflik en -spanning by skole wees nie - die media is in die eerste instansie slegs die boodskapper. Snyman (1971:505) wys daarop dat beriggewing nie opruiend en/of afbrekend hoef te wees nie: "Met die koms van die nuusmedia het dit moontlik geword om die gerug met sy vernietigende werking, doelbewuste verdraaiing, fluisterveldtogte ens., te bekamp met 'n nugter informasiediens".

\section{Ten slotte}

Die media het hulleself die rol van waghonde en toesighouers toegeëien, maar of hulle hierdie taak met verantwoordelikheid vervul met betrekking tot die verslaggewing van rassisme in Suid-Afrikaanse skole is te betwyfel. Deur selektiewe beriggewing, blaamlegging, stereotipering en emosionele taal word rassisme nie net in stand gehou nie, maar ook uitgebou. Dit wil voorkom asof sirkulasiesyfers vir baie joernaliste en/of koerantredakteurs belangriker is as rasseharmonie en samewerking in 'n geïntegreerde skolestelsel. Rassisme en rassekonflik by skole word dikwels in subjektiewe beriggewings aan die groot klok gehang ter ondersteuning of verwerping van politieke argumente. Omdat die SuidAfrikaanse leserspubliek groot vertroue in die gedrukte media stel, moet die media daarna strewe om deur gebalanseerde beriggewing oor rassekonflik rasseharmonie te bevorder en nie te vernietig nie. Dit beteken nie dat die felheid van rassegeweldsituasies verswyg moet word nie, maar dat daar in eerlike, gebalanseerde berigte op die standpunte, belewing, vrese en onderwysideale van sowel blank as swart gefokus sal word.

Op grond van die analise is dit onmoontlik om die omvang en intensiteit van rassekonflik by skole te bepaal. Redaksionele beleid en die nuuswaardigheid van gebeure bepaal wat gepubliseer gaan word en waaraan prominensie verleen gaan word. Uit die kwantitatiewe inligting 
blyk dit dat daar gedurende die periode Januarie 1985 tot Februarie 2000, 2539 berigte oor rassisme in die onderwys in Suid-Afrikaanse koerante verskyn het. Op die oog af kom rassekonflik en -spanning dus algemeen voor. Dit moet egter nie uit die oog verloor word dat verskeie berigte in dieselfde en verskillende koerante dikwels oor dieselfde gebeure handel nie.

Die Suid-Afrikaanse regering (Mbeki, 2000a:7; 2000b:2), die onderwys (James, 2000:4) en gedrukte media (Pityana, 2000:1-2) is verbind tot die verwydering van rassisme uit die Suid-Afrikaanse samelewing in die algemeen, en die onderwys en die perswese in die besonder. Maar tot tyd en wyl die liefdesgebod (Matt. 22:37-39) deur elke Suid-Afrikaner geïnternaliseer word, sal rassisme voortbestaan.

\section{Bibliografie}

ANSTEY, G. \& LEDWABA, L. 1997. School at war. Sunday Times: 5, May 18.

BENEDICT, R. 1943. Race and racism. London: The Scientific Book Club.

BERGER, A.A. 1991. Media research techniques. Newbury Park : Sage Publications.

BERRY, B. \& TISCHLER, H.L. 1978. Race and ethnic relations. Boston : Houghton Mifflin.

BHANA, D. 1999. Education, race and human rights in South Africa. Perspectives in Education, 18(2):19-30.

BISSETTY, K. 1998. School rocked by allegations of assault, abuse. The Daily News: 3, Oct. 29.

BLACK, J. \& WHITNEY, F.C. 1989. An introduction to mass communication. (In Biagi, S., ed. Media/Reader. Perspectives on mass media industries, effects and issues. Belmont, California : Wadsworth. p. 9-16.)

BONTHUYS, J. 1999. Verslag toon rassisme hoort nog nie tot verlede in skole. Die Burger: 2, Sept. 20.

BROOK, D.L. 1996. From exclusion to inclusion: racial politics and South African educational reform. Antropology \& Education Quarterly, 27(2):204-231.

COETZEE, S. 1997. Rassegevegte breek weer in Pta-skool uit. Beeld: 4, Mei 15.

CHRISTIANS, C.G. \& CAREY, J.W. 1981. (In Stempel, G.H. \& Westley, B.H., eds. Research methods in mass communication. Englewood Cliffs : Prentice-Hall. p. 342-362.)

DEFLEUR, M.L. \& DENNIS, E.E. 1985. Understanding mass communication. Dallas : Houghton Mifflin.

DE KOCK, G. 1997. Ouers erg bekommerd na rasgeveg by skool. Rapport: 12, Mei 18.

DE KOCK, G. 1998. Kole smeul nog by skool in Vryburg. Rapport: 12, Mrt. 1.

DE LANGE, F. 1997. Police called in as white, black pupils clash. The Citizen: 3, May 14.

DE MEYER, J. \& JOUBERT, J. 1999. Integrasie sal werk, dog skêrsteek kan skool knak. Beeld: 11, Mrt. 18.

DIE AFRIKANER. 1998. HNP veroordeel rasse-onluste by Hoërskool SchweizerReneke. p. 5, Febr. 13.

DIE AFRIKANER. 1999a. Rasse-onluste by Hoërskool Akasia. p. 1, Apr. 30.

DIE AFRIKANER. 1999b. Vryburg kry toe swart adjunk-hoof. p. 12, Jul. 2.

DIE AFRIKANER. 1999c. ANC speel woer-woer met Kuschke. p. 12, Sept. 10. 
DIE AFRIKANER. 1999d. Nog optrede teen rassisme. p. 2, Des. 3.

DIE BURGER. 1996. Gemengde skole-atletiek in Eikestad oor geweld gestop. p. 1, Febr. 26.

DIE VOLKSBLAD. 1995. Sy posisie is bemoeilik deur magspel in onderwys, sê Belot. p. 2, Jun. 1.

DLAMINI, S. 1999. School violated our human rights. City Press: 2, Dec. 5.

EASTERN PROVINCE HERALD. 1995. Grey expulsions. Answers needed. p. 4, Sept. 19.

ERASMUS, E. 1999. Vryburg se skêrseun getuig hy voel pyn toe hy k-woord hoor. Beeld: 4, Aug. 20.

EVELETH, A. 1997. Why can't they go back to Soweto? Mail \& Guardian: 6, May 16. EVENING POST, 1985. Apartheid education at root of race prejudice. p. 6, Febr. 5. FOURIE, C. 1999. Ben Viljoen kry reg om te transformeer. Beeld: 1, Mrt. 17.

FOWLER, R. 1991. Language in the news. London : Routledge.

FRONEMAN, J.D. 1997. Towards a Christian model for journalism. Koers, 62(1):117.

GOVENDER, S. 1999. School apology for racism. The Leader: 1, Aug. 20.

GUNNING, E. 2000. Mbeki verklaar oorlog teen rassisme. Rapport: 4, Febr. 6.

HARTLEY, J. 1985. Understanding news. London : Methuen.

HSIA, H.J. 1988. Mass communication research methods: a step-by-step approach. Hilldale : Lawrence Erlbaum Associates.

JAMES, W. 2000. Values, education and democracy.

Http://www.polity.org.za/govdocs/ reports/education/eduvalues.htm. (Consulted on 2000-05-22.)

JANKOWSKI, N.W. 1991. Qualitative research and community media. (In Jensen, K.B. \& Jankowski, N.W., ed. A handbook of qualitative methodologies for mass communication research. London : Routledge. p. 161-174.)

JASSAT, I. \& AHMED, A. 1999. Stand up for Layla's rights! City Press: 18, Oct. 3.

JONES, J.M. 1997. Prejucice and racism. New York : McGraw-Hill.

JOUBERT, J. 1998. Rasse-onmin dreig by Rustenburg-skool. Beeld: 4, Febr. 4.

LEDWABA, L.S. 1999a. It is a different and scary world in the classroom of Vryburg High. Sunday World: 4, Mrt. 7.

LEBWABA, L.S. 1999b. Race school head probed. Sunday World: 4, Sept. 5.

LEDWABA, L.S. \& MAKGOTHA, S. 1999. Principal fired after our racism exposé. Sunday World: 1, Sept. 12.

LEDWABA, L.S. \& SAKUNEKA, M. 1999. Apartheid school backlash. Sunday World: 1, Aug. 29.

MACDOUGALL, C.D. 1977. Interpretative reporting. London : Collier MacMillan.

MACLEAN, E. 1988. Between the lines: how to detect bias and propaganda in the news and everyday life. Montreal : Black Rose Books.

MARINOVICH, B. 1992. Back to school ... Sunday Tribune: 6, Oct 7.

MAMALLA, K. 1999. Moves to curb race incidents at school. Sowetan: 4, Sept. 8.

MANGXAMBA, S. 1999. Shaving row sparks school racism claims. Eastern Province Herald: 10, Nov. 24.

MATHIANE, N. 2000. Media racism reports flawed, academic says. Business Day: 12, Mrt. 7.

MBEKI, T. 2000a. Speech by Thabo Mbeki at the opening session of the National Conference on racism. Http://www.polity.org.za/govdocs/speeches/2000/sp0830. Htm. (Consulted on 24-11-2000.) 
MBEKI, T. 2000b. State of the national address by President Mbeki. Http://www.polity. org.za/govdocs/speeches/2000/sp0204. Htm. (Consulted on 24-11-2000.)

MCQUIL, D. 1993. Media performance. London : Sage Publications.

MCQUIL, D. 1987. Mass communication theory. London : Sage Publications.

MERRILL, J.C. 1984. News medium, news, objectivity - ontological questions in journalism. Ecquid Novi, 5(2):79-82.

MERRILL, J.C., LEE, J. \& FRIEDLANDER, E.J. 1990. Modern mass media. New York : Harper \& Row.

MLAMBO, S. 1997. Chaos as 100 kids break out of 'racist' reformatory. City Press: 3 , Oct. 26.

MOGALE, C. 1999. Teach, do not condemn. Nothing but the truth. City Press: 6, Jul. 4.

MONARE, M. 1999. Parents in race row after pupil (8) 'head-butted'. Pretoria News: 1, May 14

MULAUDZI, H. 1999. Racist Kuschke High still has no principal. City Press: 4, Sept. 19.

MULLER, P. 1990. Leserbehoeftes: 'n Nuwe vorm van sensuur? Ecquid Novi, 11(2):225-231.

MYTTON, G. 1983. Mass communication in Africa. London : Edward Arnold.

NEWTON, R. 1989. Roles, rights and responsibilities: whom should the media serve? (In Biagi, S., ed. Media/Reader. Perspectives on mass media industries, effects and issues. Belmont, California : Wadsworth. p. 3-8.)

NAIDOO, S. 1999. Racism stoked in schools. Independent on Saturday: 3, Jun. 26.

NAIDU, W. 1999. Edenvale school moves to stamp out racism, The Star: 19, Mrt. 5.

OOSTHUIZEN, T.H. 1982. Mediaduplisering: 'n teoretiese en empiriese ontleding van mediagebruik. Bloemfontein : UOVS. (M.A.-verhandeling.)

PILLAY, P. 1995. The first term of the future. The Natal Witness: 5, Mrt. 8.

PITYANA, N.B. 2000. Faultlines: Inquiry into racism in the media. Http://www.polity. org.za/govdocs/reports/hrc/racisme-media-summ.htm. (Consulted on 2000-0509.)

RABOROKO, J. 1997. Tension at mixed schools continues. Sowetan: 5, Aug. 12.

RAPPORT, 1997. Groepe moet met mekaar praat, glo leerling-leiers. p. 12, Mei 18.

RIGBY, P. 1996. African images. Oxford : Berg.

RSA (Republic of South Africa). 2000. Promotion of Equality and Prevention of Unfair Discrimination Act. Act No. 4 of 2000. Pretoria : Government Printers.

SAHRC (South African Human Rights Commission). 1999a. Investigation into racism in the media. Interim report. Http://www.sahrc.org.za/braude_media_report.PDF. (Consulted on 2000-05-09.)

SAHRC (South African Human Rights Commission). 1999b. Report on racism, racial integration and desegregation in South African public secondary schools. Http://www. Sahrc.org.za/final_combined_school_racism_report.html. (Consulted on 2000-05-09.)

SAHRC (South African Human Rights Commission). 2000a. South African Human Rights Commission inquiry into racism in the media opening statement. Http:/www.polity.org.za/ govdocs/pr/2000/pr0301d.html. (Consulted on 2000-0619.)

SAHRC (South African Human Rights Commission). 2000b. Investigation into racism in the media. Background to the investigation. Http://sahrc.org.za/background to the investigation.html. (Consulted on 2000-06-19.)

SIMULA, M. 1995. Are parents up to it? The Argus: 28, Jan. 25. 
SOUTHERN AFRICA REPORT. 1995. Racism flares between Coloureds, blacks. p. 5, Apr. 21.

SOUTHERN AFRICA REPORT. 1996. Radicalism surfaces in North, E Cape provinces. p. 4-5, Febr. 2.

SNYMAN, P.G. 1971. Pers en leser. Potchefstroom : Pro Rege-Pers.

STEEK, B. 2000. Media institutions are credible, according to public. Mail \& Guardian: 4, Mrt. 10.

STEMPEL, G.H. 1981. Content analysis. (In Stempel, G.H. \& Westley, B.H., eds. Research methods in mass communication. Englewood Cliffs : Prentice-Hall. p. 132-143.)

STRELITZ, L. \& STEENVELD, L. 1998. The fifth estate: media theory, watchdog of journalism. Ecquid Novi, 19(1):100-110.

SUNDAY TIMES. 1997. Chris and Gainah: a tale of two children. p. 5, May 18.

SUNDAY WORLD. 1999. Naught for the pupils' comfort. p. 4, Mrt. 7.

SYLVESTER, E. 1999. Clearing Vryburg's racial cobwebs. Saturday Star. 6, Aug. 21.

TEFFO, L.J. 1994. Racism as an escapism: who is the victim? Maseno Journal of Education, Arts and Science, 2(1):65-70.

THE CAPE TIMES. 1996a. The ' $k$ ' word - 'sometimes they use it, but discreetly'. p. 4, Sept. 6.

THE CAPE TIMES. 1996b. Teachers get to grips with change in the classroom. p. 4, Sept. 6.

THE CITIZEN. 1997. Police probing charges after race clash. p. 3, May 16.

THOMAS, R.M. 1990. International Comparative Education. Oxford : Pergamon.

THOMASSON, E. 1999. Integrating schools. Sowetan: 8, Apr. 27.

THOMPSON, D. 1998a. 3 bruin leerlinge in hospitaal na aanval deur wit kinders. Beeld: 1, Febr. 6.

THOMPSON, D. 1998b. Skelwoorde reën glo op swart leerlinge. Beeld: 1, Febr. 7.

TROYNA, B. \& HATCHER, R. 1992. Racism in children's lives: a study of mainlywhite primary schools. London : Routledge.

VAN DE GRAAF, H. 1995. Gemengde skole broeineste van onheil. Die Patriot: 2, Febr. 24.

VAN DEVENTER, J.H. 1990. Die massamedia en politieke hegemonie. Ecquid Novi, 11(2):215-224.

VAN DIJK, T.A. 1987. Communicating racism. London : Sage Publications.

VAN DIJK, T.A. 1993a. Elite discourse and racism. London : Sage Publications.

VAN DIJK, T.A. 1993b. Analysing racism through discourse analysis. (In Stanfield, J.H. \& Dennis, R.M., ed. Race and ethnicity in research methods. London : Sage Publications. p. 92-134.)

VERSLUIS, J. 1998. Seun beseer in bakleiery by VS skool. Die Volksblad: 2, Mrt. 3.

VREY, T. 2000. Rassisme nie 'n faktor in skool, sê LUR. Beeld: 9, Jan. 26.

WALDNER, M. 2000. Ons is nie Suid-Afrika se kampioen-rassiste. Perspektief Rapport: 1, Jun. 25.

WANTA, W. \& MAHMOUD, M. 1991. Factors affecting media agenda-setting: an exploratory study. Ecquid Novi, 12(1):32-45.

WINDAHL, S., SIGNITZER, B. \& OLSON, J.T. 1998. Using communication theory. London : Sage Publications.

\section{Kernbegrippe:}

rassestereotipering

rassisme in die gedrukte media 
rassisme in die S.A.onderwys

Key concepts:

race stereotyping

racism in S.A. education

racism in the printed media 